\title{
MOTHER TONGUE USAGE IN PRIMARY SCHOOLS: A DESIDERATUM FOR ACTUALIZING EDUCATION FOR ALL IN EBONYI STATE; SOUTH EAST NIGERIA.
}

BY

\author{
CHIMA, UZOMA OKPO \\ E-Mail: uzoamakachima@yahoo.com \\ Department of Igbo Language \\ Ebonyi State College Of Education Ikwo \\ Ebonyi State.
}

\section{DR. EMEKA A. NWACHUKWU}

E-Mail: princejaja73@yahoo.com Department of Educational Foundations Ebonyi State College Of Education Ikwo Ebonyi State.

\section{CELESTINE N. NWELE}

E-mail: celestinenwele@yahoo.ccom

Department of Chemistry

Ebonyi State College Of Education Ikwo

Ebonyi State.

\begin{abstract}
The study was carried out to investigate the use of mother tongue usage in teaching primary school pupils as a desideratum for actualizing EFA in Ebonyi State. The population of the study was 1,149 made up of 1,109 teachers and 40 Head teachers of the schools in the study area. Out of the population of teachers, 160 was sampled using stratified random sampling technique, while the 40 Head teachers was taken for the study. Cronpuch alpha method was utilized to ascertain consistency of the instrument which yielded a coefficient of 0.82. Mean and standard deviation was used to answer the research questions, hypotheses were tested using t-test statistic at 0.05 level of probability, findings of the study showed that 24 items in mother tongue usage were needed; while there was no significant difference in the opinions on the use of mother tongue for actualizing EFA and recommendations were made.
\end{abstract}

Key words: Mother Tongue Usage; Primary Schools, Education For All, Ebonyi State. 


\section{Introduction}

Education is the actualization of knowledge, skills, and attitude as well as value and habit. It embraces all facets of learning: cognitive, psychomotor, affect or emotional and social activities. Illeris, (2002) education is fulcrum through which scientific, social economic transformation revolves; therefore, it is vital for national development. In recognition of the importance of education to the society, the international community and government all over the world have made concrete efforts for all citizens to have access to education. These recognition is exemplified in the establishing of education for all goals at Jomtein (Thailand) in 1990 to bring the benefit of education forum in Darkar, Senegal (UNESCO, 2011).

In a bit to facilitate the actualization of EFA in Nigeria, the federal government embark on Universal Basic Education (UBE). According to the implementation guidelines, the aims of the programme where to:

i. Reduce drastically the incidence of drop-out rate from school.

ii. Carter for the learning need of young person's through appropriate tested forms of complementary approaches.

iii. Ensure that actualization of appropriate levels of literacy, moral and civic values needed for laying a solid foundation for lifelong learning.

In Nigerian primary schools, the need for the realization of EFA was emphasized as primary education is the pivot without which all other educational activities cannot stand,(Osam, Ekpo, Ibe and Imono,2011). According to the authors, primary education is the education given in an institution for children aged six years and above. It constitutes the bedrock upon which the entire educational system is built.

Alli,(2012) observed that many school age children in Nigeria are still out of school. Failure of the primary school age children to reach the last class in school has attributed to some factors which include inadequate supply of infrastructural facilities, teachers lack of mother tongue in teaching among others. Information from World Bank (2006) revealed that less than 60 percent of primary school pupils who enrolled in primary one complete their primary six bench mark. This implies that about 40 percent of that number drop-out of school before reaching primary six.

Mother tongue (MT) is the first language (FL) acquired by the child; (Mbah, 2012). According to the author, it is the language that the child learns unconsciously from the people around him. It is the language which the child learns to develop his mental and physical power to face challenges in his immediate environment or the society. Research shows that children who have strong foundation in their local language are more successful in school and enjoy greater feeling of self-worth and identity (UNESCO, 2011).Therefore, there is the need to employ the use of mother tongue in teaching, especially pupils in primary schools through mother tongue instructions (MTI).

Mother tongue instruction (MTI) is the act of teaching the learner's using their native language as a medium of instruction (Foley, 2012). The author refers to education as a child's first language (L1) usually with a planned gradual transition to a second language (L2) or foreign language at specified time in primary schools. 
In Ebonyi State, a typical Igbo speaking tribe in south east Nigeria, the researcher observed that pupils are taught using mother tongue (MT) did better than their counterparts taught using English language. Dutcher, (2005) stated that pupils who are taught using mother tongue (MT) are five times less likely to repeat classes and three times less likely to drop-out from primary schools. There are lot of challenges facing children in primary schools who are taught in other languages than their mother tongue(MT) for instance in Ebonyi State children that manage to graduate from primary school find it difficult to cope in secondary school due to the influence of English language which is not their mother tongue. Most of them drop-out not only in primary school but also in secondary school and so form a bulk of semiilliterate group that constitute nuisance to their immediate and wider society. Based on these similar problems and challenges, they was the need to ascertain a way out of the critical challenges through their perception of class room teachers and Head teachers at the basic educational level.

The general purpose of the study, therefore was to determine the perception of teachers and Head teachers on the use of (MT) in primary schools for actualizing education for all in Ebonyi State; south east Nigeria. Specifically, the sought to determine teacher's and Head teacher's perception:

i. $\quad$ Prospects of mother tongue Igbo usage in teaching primary schools in Ebonyi State.

ii. Limitations of mother tongue usage in teaching primary schools pupils in Ebonyi State.

iii. Strategies for the use of mother tongue in teaching primary school pupils for actualizing education for all (EFA) goals in Ebonyi State.

\section{Method}

The study adopted the descriptive survey design. Descriptive survey design according to Nworgu, (2006) is one in which a group of people or analyzing data from a few people or items considered to be representative of the entire group; using questionnaire developed from reviewed literature to collect data from the respondents. The population was 1,149 primary school teachers from 1,117 primary schools in Ebonyi State. A sample of 200 (160 teachers and 40 Head teachers) was obtained for use in the study through stratified proportionate random sampling technique. The number of Head teachers was relatively small and therefore used as part of sample for the study.

The instrument for data collection was 25 item mother tongue questionnaire (MTIQ) developed by the researcher and face validated by three experts; two in language education and one in measurement and evaluation all from Ebonyi State University Abakaliki. The instrument consisted of 94 point rating scale of strongly agree (SA), agree (A) and disagree (D).

The cronpach alpha method was utilized to determine the internal consistency which yielded coefficient of 0.82. The respondents were requisite of their responses on a 4 point rating scale indicating of Strongly Agree (SA), Agree (A), Disagree (D) and Strongly Disagree (SD) of 4,3,2 and 1 respectively.

The questionnaire was administered on the respondents with the help of three research assistants. After three weeks, all the 200 copies of the instrument was returned completed through same research assistants. Mean and standard deviation (SD) scores were utilized to answer the research questions, while the t-test statistics was used to test the hypotheses at 0.05 level of probability. 


\section{Results}

The results of the study were obtained from the research questions answered and the hypotheses tested through data collected and analyzed.

\section{Research Question 1:}

What are the prospects of the use of mother tongue as perceived by teachers and Head teachers of schools in teaching pupils in primary schools in Ebonyi State?

$\mathbf{H}_{\mathbf{0}}$ 1: There is no significant difference in the mean ratings of the responses of teachers and Head teachers of schools on the prospects of mother tongue usage in teaching pupils in primary schools in Ebonyi State. The analysis of the research questions and hypothesis presented in table: 1

Table 1: Mean ratings and t-test analysis of the responses of teachers and school head teachers on the prospects of mother tongue usage in teaching primary school pupils. $\mathrm{N}=200$

\begin{tabular}{lllllll}
\hline S/N & Item statement & $\mathbf{X}$ & SD & t-cal & t-tab & RM \\
\hline 1 & Enhance easy transition from home to school. & 3.65 & 0.47 & 1.46 & 1.96 & N,NS \\
2 & Facilitates understanding & 3.79 & 0.68 & 1.30 & 1.96 & N,NS \\
3 & Reduces rate of learner's failure in examinations & 3.36 & 0.54 & 0.78 & 1.96 & N,NS \\
4 & Reduces rate of school drop-out & 3.75 & 0.76 & 1.43 & 1.96 & N,NS \\
5 & Provides linguistics tools for sustainable development. & 3.48 & 0.65 & 1.48 & 1.96 & N,NS \\
6 & Encourages self-reliance and resourcefulness. & 3.61 & 0.62 & 1.17 & 1.96 & N,NS \\
7 & Ability to learn better and faster & 3.49 & 0.81 & 1.76 & 1.96 & N,NS \\
8 & Encourages enrolment and regular attendance to school. & 3.62 & 0.71 & 0.32 & 1.96 & N,NS \\
9 & Enculturation of the child within the culture of his or her & 3.04 & 0.79 & 1.44 & 1.96 & N,NS \\
& society. & & & & &
\end{tabular}

KEY: $\quad \mathrm{N}=$ Needed $\mathrm{SD}=$ standard deviation $\mathrm{X}=$ Mean: NS = Not significant

The data in table 1: Revealed that the items had their mean ranged from 3.36-3.79 and were above the cut-off point of 2.50. Therefore, there were perceived as prospects in the use of mother tongue in teaching primary school pupils. The items had their standard deviations ranged from $0.47-0.81$ which indicated the respondents were not far from the mean and were close to one another in their responses. The table also indicated that each of the 7 items had its calculated t-value lower than table value of 1.96. This showed that there was no significant difference in the mean ratings of the responses of teachers and Head teacher with reference to prospects of using mother tongue in teaching primary school pupils.

\section{Research Question 2:}

What are the constraints of the mother tongue as perceived by teachers and Head teachers in teaching pupils in actualizing education for all (EFA)?

Ho2: What are the constraints of the mother tongue as perceived by teachers and Head teachers in teaching pupils in actualizing education for all (EFA)? 
Table 2: Mean ratings and t-test analysis of the responses of teachers and school head teachers on the constraints of the use of mother tongue in teaching primary school pupils in actualizing education for all (EFA).

\begin{tabular}{llccccc}
\hline S/N & Item statement & $\mathbf{X}$ & $\mathbf{S D}$ & $\mathbf{t}$-cal & t-tab & Rank \\
\hline 1 & $\begin{array}{l}\text { Only the indigenous language curriculum are available } \\
\text { in indigenous languages. }\end{array}$ & 3.05 & 0.43 & 0.59 & 1.96 & N,NS \\
2 & $\begin{array}{l}\text { Textbooks of the subjects taught in primary schools are } \\
\text { written in English language. }\end{array}$ & 3.86 & 0.68 & 0.18 & 1.96 & N,NS \\
$3 \quad \begin{array}{l}\text { Most primary school teachers do not have any formal } \\
\text { education training in indigenous languages. }\end{array}$ & 3.51 & 0.48 & 0.42 & 1.96 & N,NS \\
$4 \quad \begin{array}{l}\text { Parents adherence to the use of English language in the } \\
\text { family up-bringing of their children }\end{array}$ & 3.50 & 0.46 & 1.45 & 1.96 & N,NS \\
$5 \quad \begin{array}{l}\text { Societal belief that English language is superior to } \\
\text { indigenous (mother tongue) language. }\end{array}$ & 3.65 & 0.36 & 1.36 & 1.96 & N,NS \\
$\quad$ Non implementation of the language policy. & 3.43 & 0.72 & 1.23 & 1.96 & N,NS \\
7 & Unwillingness to changes. & 3.40 & 0.85 & 0.87 & 1.96 & N,NS \\
\hline
\end{tabular}

KEY: $\quad \mathrm{X}=$ Mean, SD - standard deviation

$\mathrm{t}=\mathrm{cal}=\mathrm{t}-$ calculated, $\mathrm{t}-\mathrm{tab}$

$\mathrm{t}=$ table value

The data in table 2 revealed that the 7 items had their mean score ranged from 3.05-3.86 and each was above the cut-off point of 2.50. This indicates that all the items were perceived by teachers and Head teachers as constraints in teaching primary school pupils using the mother tongue. The items had their standard deviations ranged from 0.43-0.85 which showed that the respondent were not far from the mean and were close to one another in their opinions. The table also revealed that each of the 7 items had its calculated t-value lower than t-table value of 1.96. This showed that there was no significant difference in the mean ratings of the responses of teachers and Head teachers on the constraints of mother tongue usage in teaching primary school pupils for actualizing education for all (EFA). Therefore, the hypothesis of no significant difference was upheld for the items.

\section{Research Questions 3:}

What are the strategies needed for the promotion of mother tongue usage in primary schools as perceived by teachers and Head teachers of schools?

Ho3: There is no significant difference in the mean ratings of the responses of teachers and Head teachers on the strategies for the formation of the use of mother tongue in teaching primary school pupils.

Table 3: Mean ratings and t-test analysis of the responses of teachers and head teachers the strategies needed for the promotion of the use of mother tongue in teaching primary school pupils.

\begin{tabular}{lllllllll}
\hline $\mathbf{S} / \mathbf{N}$ & Item statement & & & $\mathbf{X}$ & SD & t-cal & t-tab & Rank \\
\hline 1 & $\begin{array}{l}\text { Translation } \\
\text { language. }\end{array}$ & & & & & & & \\
&
\end{tabular}




\begin{tabular}{|c|c|c|c|c|c|c|}
\hline 2 & $\begin{array}{l}\text { Inclusion of indigenous language vocabulary that emphasize } \\
\text { science and technology in the curriculum. }\end{array}$ & 3.86 & 0.57 & 0.78 & 1.96 & $\mathrm{~N}, \mathrm{NS}$ \\
\hline 3 & $\begin{array}{l}\text { Making all instructional materials available in indigenous } \\
\text { language. }\end{array}$ & 3.50 & 0.50 & 1.37 & 1.96 & $\mathrm{~N}, \mathrm{NS}$ \\
\hline 4 & In-service training of teachers in indigenous language. & 2.89 & 0.76 & 1.36 & 1.96 & $\mathrm{~N}, \mathrm{NS}$ \\
\hline 5 & $\begin{array}{l}\text { Public awareness campaigns on the benefits/prospects of } \\
\text { mother tongue usage. }\end{array}$ & 3.43 & 0.44 & 1.17 & 1.96 & $\mathrm{~N}, \mathrm{NS}$ \\
\hline 6 & $\begin{array}{l}\text { Monitoring to ensure implementation of the language policy } \\
\text { in primary school. }\end{array}$ & 3.71 & 0.49 & 0.32 & 1.96 & $\mathrm{~N}, \mathrm{NS}$ \\
\hline 7 & $\begin{array}{l}\text { Giving incentives to schools that implement the policy on } \\
\text { mother tongue usage. }\end{array}$ & 3.62 & 0.57 & 0.32 & 1.96 & $\mathrm{~N}, \mathrm{NS}$ \\
\hline
\end{tabular}

The data in table-3 revealed that all the 7 items had their means ranged from 2.89-3.86. This showed that each of the items had a means above the cut-off point of 2.50 which meant that all the strategies were needed for the promotion of mother tongue usage. The table also revealed that the items had their standard deviation values ranged from 0.44 to 0.76 ; this showed that the respondents were out far from the mean and were not close to one another in their opinions.

The result of the hypothesis in table 3 indicated that each of the items has the calculated t-values lower than the table value of 1.96. This means that there was no significant difference in the mean rating of the response of teachers and Head teachers of schools on strategies needed for the promotion of mother tongue usage for the actualization of education for all (EFA); therefore, the hypothesis of no significant difference was uphold for the 7 items.

\section{Discussion of Result}

Result of the study in table 1 showed that 9 items were perceived by teachers of primary school pupils as prospects in using mother tongue to teach primary school pupils for the actualization of education for all (EFA). The result of the study is in consonant with that of Ball, (2012) who stated that one of the ways of achieving equity in educational opportunities, education for all, (EFA), as well as counting linguistics and cultural loss as to deliver early childhood education through the use of mother tongue.

In table 2: the result of the study showed that 7 items were perceived as constraints in teaching mother tongue usage in teaching primary school pupils. These findings agreed with that of Babalola (2002) who stated that language provision in national policy on education is being pursued without any degree of seriousness. The result in table- 3 revealed that 7 items were perceived by teachers and Head teachers as strategies to be used by teachers in teaching primary school pupils using mother tongue in order to realize education for all (EFA). This finding agrees with that of Okediadi, (2010) who find out that one of the strategies to adopt in teaching primary school pupils using their mother tongue to monitor the implementation of language policy.

\section{Recommendations}

Based on the findings of the study, the following recommendations are made:

1. Parents should encourage the use of mother tongue in their homes. 
2. Parents should be reading or telling stories in their mother tongue in order to develop their oral and vocabulary skills.

3. Indigenous language should made compulsory courses for teacher training in colleges of education so that they will be well equipped to teach effectively using mother tongue in basic schools.

4. Incentives should be given to schools and teachers that implement the use of mother tongue instruction (MTI) policy and sanction to those who refuse to comply.

5. Government should organize in-service training programmes for serving teacher in the use of mother tongue in teaching primary school pupils.

\section{Conclusion}

Mother tongue usage that is the use of mother tongue in teaching primary school pupil was found to be a desideratum or a way out to avert problems or challenges of pupils dropping out of school before completion. In addition using the native language facilitates better performance of students in post-primary schools. Undoubtedly, if the state government can implement the recommendation adduced in the study; the problems or challenges of education for all programs due to the use of foreign languages in teaching primary school pupils would be a thing of the past.

\section{References}

[1] Alli, L.A.: Will Nigeria achieve education for all by 2015? Retrieved June, 2013 from http://www.information.ng.com/2012/11/will-nigeria-achieve-education-for-all-by-2015.html (2012).

[2] Babalola, V.O.: Sustainability of the teaching and learning of Nigeria language as first and second languages. Journal of the world council for curriculum and Instruction and Instruction, Vol. 3, pp. 1-9. (2002).

[3]Ball, J.: The importance of mother tongue. Retrieved June, 2013 from http://www.navhindtimesin/pnnorama/importance-mother-tongue (2012).

[4] Ditcher, P.N.: In their own language-education for all. Education Notes. World Bank Retrieved June, 2013 from http://siteresoures.worldbank.0.5 /education/resources/educationnotes/Ednotes-long-of-Instruction (2005).

[5]Foley, A.: Mother-tongue education in south Africa. Retrieved June, 2013 fromhttp://englishacademy.co.za/pansa 16/educationa.pdf (2012).

[6] Ileris, K.: Learning theory retrieved from https:academah.com.management (2002).

[7] Mbam, B.M.: Language policy mother tongue education and role of the Nigeria language teacher in Nigeria language education. Journal of Education and practice, pp. 3348-54 (2012).

[8] Nworgu, B.G.: Educational research basis issues and methodology ( $2^{\text {nd }}$ enlarged ed). Nsukka: University Trust publishers (2006).

[9] Okediadi N.: Literacy in the mother tongue: Policy, versus preference, a case of study awka, educational, zone. Journal of Igbo studies, Vol.5, pp. 88-96 (2010).

[10] Osam, O.E., Ekpo, K., Ibe, J.O. \& Imona, M.E.: Reflective elements in the development of peace education. Curriculum in Nigeria primary schools. Journal of curriculum and instrument, vol. 8, pp. 74-79 (2011).

[11]UNESCO, : Education for all agenda. Retrieved June, 203 from http://www.un.org/en/ecosoc/docs/book 201/05-Dialogues\%20at\% 20ECOSOC\%202011-A. 
The \% 20Education\%20for\% 20All \% 20Agenda. Pdf (2011).

[12]World Bank.: Education For All (EFA). Retrieved June, 2013 from http://webbank.org./WEBSITE/EXTERNAL/TOPICS/exteducation/D,content

MDK: 20374062-menupk:540090. Pagepk:143956-Pipk:216618-thesitepk:282386,00.html (2006). 